\title{
Non-stationary catalytic cracking of methane over ceria-based catalysts: Mechanistic approach and catalyst optimization
}

\author{
E. Odier, Y. Schuurman, C. Mirodatos * \\ Institut de Recherches sur la Catalyse et l'Environnement de Lyon-IRCELYON UMR 5256 CNRS/Université Lyon 1, 2 Avenue Albert Einstein, \\ F-69626 Villeurbanne Cedex, France
}

\begin{abstract}
The non-stationary cracking of methane over various noble metal/ $\mathrm{CeO}_{2}$-doped catalysts at 400 and $600{ }^{\circ} \mathrm{C}$ was followed by DRIFT spectroscopy and on the basis of the identified elementary steps a simplified kinetic modeling is proposed. The production of $\mathrm{H}_{2}$ by direct decomposition of $\mathrm{CH}_{4}$ on the noble metal is improved by the capacity of ceria to store carbonaceous surface species thanks to: (i) the spillover of carbonyls from noble metal particles towards basic hydroxyls formed on partially reduced Ce sites and (ii) the reverse spillover of ceria oxygen towards metal to oxidize the carbon issued from methane cracking. The resulting formate adspecies are in turn oxidized into carbon dioxide during the regeneration step. Doping the ceria with basic lanthanide oxides and replacing Pt by more efficient and eventually better dispersed metals for methane decomposition like Rh and Ir lead to significant improvements in the hydrogen productivity.
\end{abstract}

Keywords: Methane cracking to hydrogen; Noble metals supported on ceria, Pt, Ir, Rh; Ceria doping; Transient kinetic modeling; In situ DRIFT; Non stationary processes

\section{Introduction}

Within the perspective of sustainable hydrogen production for feeding fuel cells and/or generating synthetic fuels, new catalytic processes have to be designed for meeting non-stationary conditions imposed by the targeted application. For example, frequent start-up and shutdown operations have to be foreseen for any domestic stationary or on-board reformers. Non-steady-state processes can also be considered as an alternative to conventional continuous ones, being designed specifically to take advantages of transient operations. Recently, a novel process for hydrogen production with purity higher than $90 \%$ was proposed by sorption-enhanced steam methane reforming reactions in two parallel fixed bed reactors operated in a cyclic manner. First, through addition of a $\mathrm{CO}_{2}$ sorbent into a reforming reactor, the reactions of reforming, water-gas shift and $\mathrm{CO}_{2}$ sorption were combined, and more $\mathrm{CH}_{4}$ was expected to convert $\mathrm{H}_{2}$ in one reactor. Second, regeneration of the sorbent was carried out in the

\footnotetext{
* Corresponding author. Tel.: +33 472445366; fax: +33 472445399 .

E-mail address: Claude.Mirodatos@ircelyon.univ-lyon1.fr (C. Mirodatos).
}

other reactor. The hydrogen production and sorbent regeneration processes were carried out simultaneously in the two fixed bed reactors, operated in a cyclic manner by switching a methane/ steam feed and an Ar-containing feed between the two reactors at a fixed feed switchover time [1].

On a similar basis, other promising non-stationary processes were proposed years ago, like the cyclic two-step reforming which combines a step of hydrocarbon cracking into hydrogen and carbon deposits followed by a step of catalyst regeneration, as proposed in Refs. [2-4] for the case of natural gas conversion:

step I CH $4 \mathrm{C}_{\text {deposited on catalyst }}+2 \mathrm{H}_{2}$

For this case, both the oxygen and the carbon storage capacity of the catalytic systems have to be considered as key factors for ensuring proper operations control. As a matter of fact, oxygen stored on the catalyst may partly oxidize the hydrogen formed during step I, but also favors the reoxidation in step II. In turn, a high capacity of C storage associated with fast dynamics appears as a prerequisite for such a transient process. In turn, the capacity to store carbon deposits during the 
cracking step is essential for avoiding a fast deactivation of the catalyst but also for allowing a fast and controlled regeneration that is not detrimental for the catalyst structure.

At variance with $\mathrm{Ni}$ based systems that may store carbon as carbide and graphite at high temperature $\left(700-800^{\circ} \mathrm{C}\right)$, supported noble metals, which operate at lower temperature, require $\mathrm{C}$ storage assistance from the support. For this case, a low temperature process is expected to be more efficient since the rate of adspecies diffusion on the support has to be comparable with the rate of carbon formation on metal during the cracking step.

When associated to oxygen storing materials like $\mathrm{CeO}_{2}$ and doped $\mathrm{CeO}_{2}$ solid solutions, noble metals were already recognized as effective catalysts for the partial oxidation of methane (POM), water gas shift (WGS) equilibration and selective oxidation of CO (SELOX) [5-7]. Their potential for being operated under transient conditions has already been successfully demonstrated in our group by considering the model catalyst $\mathrm{Pt} / \mathrm{CeO}_{2}$, investigated by means of in situ IR studies [8], mechanistic and kinetic modeling [4]. The exact and respective role of the metal and the support remains however a key question, which has to be answered in order to design improved materials able to meet the requirements of these relatively low temperature transient operating conditions.

As a continuation of our previous studies, this paper will first give an overview of the main findings on this model catalyst and then present new results on a series of noble metals supported on doped ceria, aiming at: (i) improving the catalysts performances and (ii) gaining a better understanding of the dynamic processes of this two-step process.

\section{Experimental}

\subsection{Materials}

High surface area ceria powder used either pure or modified by La and $\operatorname{Pr}$ oxides doping (210-180 $\mathrm{m}^{2} / \mathrm{g}$ ) (provided by
Rhodia) were first calcined at $600{ }^{\circ} \mathrm{C}$, then impregnated with an aqueous solution of $\mathrm{Me}(\mathrm{OH})_{2}\left(\mathrm{NH}_{3}\right)_{4}$ salts $(\mathrm{Me}=\mathrm{Pt}, \mathrm{Rh}$ and $\mathrm{Ir})$ at various contents. Precursors were calcined at $500{ }^{\circ} \mathrm{C}$ for $8 \mathrm{~h}$, reduced in a hydrogen flow at $300{ }^{\circ} \mathrm{C}$ for $15 \mathrm{~h}$ and then kept under inert gas (Ar) before reaction. A commercial $0.5 \% \mathrm{Pt} /$ $\gamma \mathrm{Al}_{2} \mathrm{O}_{3}$ catalyst was used as reference. The composition of all ceria-based catalysts after calcination is reported in Table 1.

\subsection{Catalysts characterization}

The specific surface area of the samples was calculated from the $\mathrm{N}_{2}$ adsorption-desorption at $-196{ }^{\circ} \mathrm{C}$ by using the BET method, after desorption under vacuum for $3 \mathrm{~h}$ at $300{ }^{\circ} \mathrm{C}$.

Noble metal dispersion was evaluated for some cases by the method of temperature-programmed reduction (TPR) over used samples. Its principle, well adapted to the case of noble metals supported on redox supports like ceria, consists in a TPD measurement carried out in the presence of hydrogen in the sweep gas [9]. Typically, the sample is first re-reduced at $400{ }^{\circ} \mathrm{C}$ in $\mathrm{H}_{2}$ flux for $4 \mathrm{~h}$, then cooled down and heated under a flux of 4 vol\% $\mathrm{H}_{2}$ in Ar from 25 to $800{ }^{\circ} \mathrm{C}$ with a ramp of $10{ }^{\circ} \mathrm{C} /$ min. By integrating the low temperature peak of hydrogen desorption (at ca. $120^{\circ} \mathrm{C}$ ), an evaluation of the noble metal dispersion was obtained.

\subsection{Testing procedure}

The reaction was carried out at $400{ }^{\circ} \mathrm{C}$ under atmospheric pressure either in fixed bed reactor ( $4 \mathrm{~mm}$ i.d.) or in an in situ DRIFT cell (SPECTRATECH, $5 \mathrm{~mm}$ i.d.) $[4,8]$. Experiments consisted in flowing alternatively $20-50 \% \mathrm{CH}_{4}$ in inert gas (during $1 \mathrm{~min}$ ), then pure inert gas (as a flush) and finally $20 \%$ $\mathrm{O}_{2}$ in inert gas (as long as necessary to eliminate all the reversible $\mathrm{C}$ stored), all mixtures with a total flow rate of $20 \mathrm{ml} /$ min (STP). The gas concentration at the reactor outlet was continuously monitored by on line mass spectrometry. For the case of DRIFT experiments, infrared spectra were recorded

Table 1

Catalysts composition and performance $\left(\mathrm{GHSV}=3400 \mathrm{~h}^{-1}\right)$

\begin{tabular}{|c|c|c|c|c|c|c|c|c|c|}
\hline \multirow[t]{2}{*}{$\mathrm{Me}$} & \multicolumn{2}{|l|}{ Catalysts } & \multirow[t]{2}{*}{ Temperature $\left({ }^{\circ} \mathrm{C}\right)$} & \multirow[t]{2}{*}{ Conversion $\%$} & \multirow[t]{2}{*}{$S_{\mathrm{H}_{2}} \%$} & \multirow[t]{2}{*}{$Y_{\mathrm{H}_{2}} \%$} & \multirow[t]{2}{*}[\mathrm{CO}]{$_{\max }(\%)$} & \multirow{2}{*}{$\begin{array}{l}\mathrm{H}_{2} \text { prodced } \\
(\mathrm{ml} / \mathrm{min})\end{array}$} & \multirow{2}{*}{$\begin{array}{l}\text { C storage } \\
\left(\mu \mathrm{g} \mathrm{C} / \mathrm{g}_{\text {cat }}\right)\end{array}$} \\
\hline & Loading (wt.\%) & Ceria doping & & & & & & & \\
\hline $\mathrm{Pt}$ & 0.8 & Undoped & 400 & 8.6 & 39.5 & 3.4 & 0.2 & 0.7 & 138 \\
\hline $\mathrm{Pt}$ & 5 & Undoped & 400 & 15.6 & 37 & 5.7 & 0.1 & 1.1 & nd \\
\hline $\mathrm{Pt}$ & 5 & $23.7 \% \operatorname{Pr}_{6} \mathrm{O}_{11}$ & 400 & 14.2 & 39.8 & 5.6 & 0.2 & 1.2 & 228 \\
\hline $\mathrm{Ir}$ & 0.5 & $10.0 \% \mathrm{La}_{2} \mathrm{O}_{3}$ & 400 & 12.5 & 47.0 & 5.9 & 0.2 & 1.3 & 464 \\
\hline $\mathrm{Ir}$ & 0.5 & Undoped & 400 & 18.9 & 39.2 & 7.4 & 0.2 & 1.6 & 187 \\
\hline Ir & 0.5 & $23.7 \% \operatorname{Pr}_{6} \mathrm{O}_{11}$ & 400 & 22.7 & 32.9 & 7.5 & 1.5 & 1.6 & 902 \\
\hline $\mathrm{Rh}$ & 0.5 & Undoped & 400 & 13.7 & 64.6 & 8.8 & 0.3 & 1.9 & 597 \\
\hline $\mathrm{Pt}$ & 5 & $14.5 \% \mathrm{ZrO}_{2}$ & 600 & 38.2 & 75.0 & 28.7 & 14.0 & 6.1 & 217 \\
\hline Ir & 0.5 & Undoped & 600 & 36.7 & 81.6 & 29.9 & 8.9 & 6.4 & 235 \\
\hline $\mathrm{Pt}$ & 5 & Undoped & 600 & 36.7 & 83.7 & 30.7 & 9.0 & 6.6 & 585 \\
\hline Ir & 0.5 & $23.7 \% \operatorname{Pr}_{6} \mathrm{O}_{11}$ & 600 & 33.6 & 92.9 & 31.2 & 8.7 & 6.7 & 377 \\
\hline $\mathrm{Rh}$ & 0.5 & Undoped & 600 & 34.1 & 92.9 & 31.7 & 10.8 & 6.8 & 361 \\
\hline $\mathrm{Pt}$ & 5 & $10.0 \% \mathrm{La}_{2} \mathrm{O}_{3}$ & 600 & 32.6 & 97.6 & 31.8 & 9.0 & 6.8 & 461 \\
\hline $\mathrm{Pt}$ & 5 & $23.7 \% \operatorname{Pr}_{6} \mathrm{O}_{11}$ & 600 & 38.5 & 84.2 & 32.4 & 9.5 & 6.9 & 228 \\
\hline Ir & 0.5 & $10.0 \% \mathrm{La}_{2} \mathrm{O}_{3}$ & 600 & 36.2 & 94.6 & 34.3 & 9.5 & 7.3 & 414 \\
\hline
\end{tabular}

The catalysts are listed and ranked according to increasing hydrogen yield. 
with a Nicolet Magna-IR 550 spectrometer, using a MCT detector with a resolution of $4 \mathrm{~cm}^{-1}$ at a frequency of one spectrum every $3 \mathrm{~s}$.

The methane conversion was calculated as the amount of methane converted along the whole cracking step over the amount admitted during that step. The selectivity was the amount of hydrogen collected at reactor outlet as dihydrogen over the total amount of hydrogen contained in the reacted methane. $\left[\mathrm{CO}_{\max }\right]$ was the highest $\mathrm{CO}$ concentration observed during the methane cracking step.

\subsection{Transient curve modeling}

In order to describe adequately the transient experimental curves, the fixed bed reactor was described as a cascade of perfectly stirred tank reactors in series, allowing us to account for the axial dispersion. For a low degree of dispersion $(\mathrm{Bo}<50)$ the number of stirred tanks, $N$, and the Bodenstein number, Bo, are related as: $N \approx \mathrm{Bo} / 2$ [4]. The fixed bed reactor was described by a system of ordinary differential equations (ode's). No radial gradients were taken into account and a onedimensional model was applied. Mass balances were developed for both the gas phase and the adsorbed phase. The reactor was considered to be isothermal.

The experimental reactor consists of three distinct zones: (1) the tubing from the switching valve to the catalyst bed, (2) the catalyst bed and (3) tubing to the mass spectrometer. Each zone was taken into account explicitly in the model. The resulting set of differential equations was solved numerically by means of an improved Euler method with variable step size control. Parameter optimization was accomplished by a Mead Nelder simplex algorithm [4].

\section{Results and discussion}

\subsection{Catalysts characterization}

\subsubsection{BET surface area}

As can be seen in Table 2, the initial high ceria surface area $\left(184 \mathrm{~m}^{2} / \mathrm{g}\right.$ after calcination at $600{ }^{\circ} \mathrm{C}$ ) was found to be slightly decreased to about 180,131 and $163 \mathrm{~m}^{2} / \mathrm{g}$ after $0.8 \% \mathrm{Pt}, 5 \% \mathrm{Pt}$ and $0.5 \%$ Ir addition, respectively. The decrease in surface area

Table 2

BET surface area for high surface area ceria material and after Pt and Ir addition and testing

\begin{tabular}{|c|c|}
\hline Support/catalyst & BET area $\left(\mathrm{m}^{2} \mathrm{~g}^{-1}\right)$ \\
\hline $\mathrm{HSA} \mathrm{CeO}_{2}$ uncalcined & $195 \pm 2$ \\
\hline HSA $\mathrm{CeO}_{2}$ calcined at $600{ }^{\circ} \mathrm{C}$ & $184 \pm 2$ \\
\hline $\mathrm{HSA} \mathrm{CeO}_{2}$ calcined at $800^{\circ} \mathrm{C}$ & $57 \pm 1$ \\
\hline $\begin{array}{l}0.8 \% \mathrm{Pt} / \mathrm{CeO}_{2} \text { calcined at } 500{ }^{\circ} \mathrm{C}, \\
\text { reduced at } 300{ }^{\circ} \mathrm{C} \text { but unreacted }\end{array}$ & $180 \pm 2$ \\
\hline $\begin{array}{l}5 \% \mathrm{Pt} / \mathrm{CeO}_{2} \text { calcined at } 500{ }^{\circ} \mathrm{C}, \\
\text { reduced at } 300{ }^{\circ} \mathrm{C} \text { but unreacted }\end{array}$ & $131 \pm 2$ \\
\hline $\begin{array}{l}5 \% \mathrm{Pt} / \mathrm{CeO}_{2} \text { after long term run at } \\
400 \text { and } 600{ }^{\circ} \mathrm{C}\end{array}$ & $42 \pm 1$ \\
\hline $\begin{array}{l}0.5 \% \mathrm{Ir} / \mathrm{CeO}_{2} \text { calcined at } 500{ }^{\circ} \mathrm{C}, \\
\text { reduced at } 300{ }^{\circ} \mathrm{C}\end{array}$ & $163 \pm 2$ \\
\hline
\end{tabular}

after metal addition (the higher the larger content of noble metal) is ascribed to the action of the acidic impregnation solution, activating the surface of $\mathrm{Ce}-\mathrm{Me}-\mathrm{O}$ particles (hydroxylated and chlorinated). This would favor a re-stacking of the primary particles and also the incorporation of part of the noble metal atoms as oxidic species within the nanodomains, forming new intercrystalline/domain boundaries, partly plugging the surface nanoporosity of the mixed oxide $[10,11]$.

A significant decrease in specific area was noted after long term catalytic tests carried out at 400 and $600{ }^{\circ} \mathrm{C} \mathrm{(ca.} 42 \mathrm{~m}^{2} / \mathrm{g}$ for $5 \% \mathrm{Pt} / \mathrm{CeO}_{2}$ ), which indicates a severe sintering of the ceria material, possibly due over heating during the regeneration steps (similar surface area decrease was obtained after ceria calcination at $800{ }^{\circ} \mathrm{C}$ ).

\subsubsection{Noble metal dispersion}

The evaluation of Me/ceria catalysts from TPR measurements gave values comprised between $12 \%$ (for $5 \mathrm{wt} \% \mathrm{Pt} /$ $\mathrm{CeO}_{2}$ ) to $30 \%$ for the 0.5 wt. $\% \mathrm{Ir} / \mathrm{CeO}_{2}$ catalysts. A slight decrease in metal dispersion was noted after catalytic tests carried out from 400 to $600{ }^{\circ} \mathrm{C}$ (e.g. 10 and $15 \%$ for the Pt and $\mathrm{Ir} / \mathrm{CeO}_{2}$ catalyst, respectively), in line with the over heating phenomena mentioned above. Note that for reference samples, a reasonable agreement in metal dispersion was obtained with SEM measurements (e.g. particles of 2-3 nm were observed for the Ir/ceria materials).

\subsection{Reaction mechanism over reference $\mathrm{Pt} / \mathrm{CeO} \mathrm{O}_{2}$}

\subsubsection{Catalytic results over $\mathrm{Pt} / \mathrm{CeO} \mathrm{O}_{2}$ sample}

Under forced non-steady-state conditions (Fig. 1), a methane conversion of ca. 9 wt. $\%$ with an $\mathrm{H}_{2}$ selectivity of ca. $40 \mathrm{wt} . \%$ was obtained at $400{ }^{\circ} \mathrm{C}$ for a gas hourly space velocity (GHSV) of $3400 \mathrm{~h}^{-1}$ during the methane pulse over the unpromoted $0.8 \mathrm{wt} . \% \mathrm{Pt} / \mathrm{CeO}_{2}$, leading to an average hydrogen yield of 3 wt.\% (Table 1). The remaining hydrogen extracted from methane was released as $\mathrm{H}_{2} \mathrm{O}$ essentially during the oxidation step. Less than $1 \% \mathrm{CO}$ was detected during methane cracking

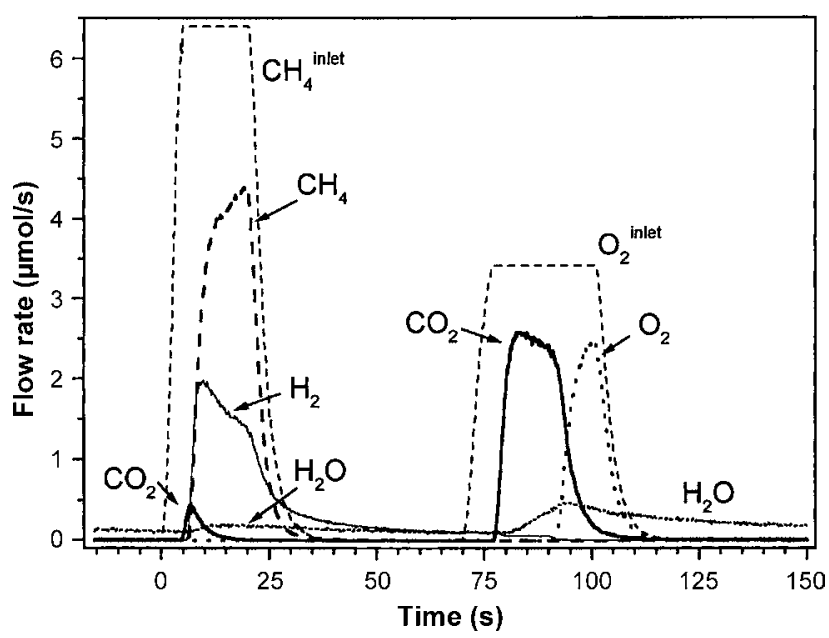

Fig. 1. Inlet and outlet gas concentrations obtained over $0.5 \mathrm{wt} . \% \mathrm{Pt} / \mathrm{CeO}_{2}$ tested at $400{ }^{\circ} \mathrm{C}$ by sequentially feeding a fixed bed reactor $(4 \mathrm{~mm}$ i.d.) with methane, then helium and then oxygen. 
into $\mathrm{H}_{2}$ or during the oxidative regeneration step, which was the prerequisite for the selection of this catalyst. Only a small $\mathrm{CO}_{2}$ peak and a permanent trace release of water were detected during the methane pulse.

\subsubsection{In situ DRIFT analysis}

Three series of IR spectra have been recorded under reaction conditions with the following samples: 0.8 wt.\% $\mathrm{Pt} / \mathrm{CeO}_{2}(\mathrm{~A})$, $\mathrm{CeO}_{2}$ (B), 0.5 wt.\% Pt/ $/ \mathrm{Al}_{2} \mathrm{O}_{3}(\mathrm{C})$. Under $\mathrm{CH}_{4}$ flow, the main kinds of observed species are listed in Table 3 and illustrated in Fig. 2: gaseous species $\left(\mathrm{CH}_{4}, \mathrm{CO}_{2}\right)$, adspecies on platinum (gem dicarbonyl, linear carbonyl, bridge-bonded and multibonded carbonyl species, depending probably on the $\mathrm{Pt}$ dispersion and interaction with the support) and adspecies on cerium oxide (hydroxyls $-\mathrm{OH}$, formates $-\mathrm{CO}_{2} \mathrm{H}$, carbonates $-\mathrm{CO}_{3}$ ), in agreement with $\mathrm{Li}$ et al. [12].

Gaseous carbon dioxide is present at the beginning of the methane pulse step I for samples $\mathrm{A}$ and $\mathrm{C}$ because of the previous regeneration of the sample by oxidation step II: the oxidized Pt surface favors initially the total oxidation of methane until $\mathrm{Pt}$ is reduced and the cracking starts.

3.2.2.1. C storage. The three samples were compared to determine precisely which kinds of adspecies participate efficiently to $\mathrm{C}$ storage. The Pt-free sample $\mathrm{B}\left(\mathrm{CeO}_{2}\right)$ shows that cerium oxide can activate methane and oxidize it into surface carbonates (see Fig. 2a). But in this case methane conversion is very low and this oxidation, which could be initiated at $200{ }^{\circ} \mathrm{C}$ [13], corresponds to the interaction of methane with surface lattice oxygen anions created by the previous regeneration step. These carbonates are essentially irreversible (only a minor part can be outgassed as $\mathrm{CO}_{2}$ during the regeneration step) and therefore cannot be considered as efficient $\mathrm{C}$ storage agents. They are also present in sample $\mathrm{A}$ (0.8 wt. \% Pt/ $\left.\mathrm{CeO}_{2}\right)$. However, at higher temperature, like under POM or methane combustion conditions, these carbonates may be decomposed easily into $\mathrm{CO}_{2}$, forming a pool of carbon but also of oxygen able to spillover towards the noble metal particles under transient conditions [14].

With sample $\mathrm{C}\left(0.5 \mathrm{wt} \% \mathrm{Pt} / \mathrm{Al}_{2} \mathrm{O}_{3}\right)$, the decomposition of $\mathrm{CH}_{4}$ on $\mathrm{Pt}$ is rapidly stopped after methane admission because the non-reducible alumina support is unable to store carbonaceous adspecies $\left(\mathrm{CH}_{4}\right.$ conversion $\left.<1 \%\right)$. Only $\mathrm{Pt}$ carbonyls are formed, resulting from $\mathrm{CH}_{4}$ partial oxidation by oxidized $\mathrm{Pt}$ sites.

On sample A $\left(0.8 \mathrm{wt} . \% \mathrm{Pt} / \mathrm{CeO}_{2}\right)$, Pt carbonyls are also detected but with different spectral characteristics: a shift of the maximum absorption (from 2061 (C) to 2042 (A) $\mathrm{cm}^{-1}$ ) followed by a shoulder around $1968 \mathrm{~cm}^{-1}$ indicates that the nature and structure of carbonyls have changed (more reduced Pt acceptors and extension from single to multi-bonded carbonyls) (Fig. 2b).

The carbonyl species, which in turn can either desorb into the gas phase or be stored on the ceria surface by reverse spillover, can only be formed thanks to oxygen provided by ceria (surface lattice oxygen which can migrate towards platinum) reacting with carbonaceous species provided by the methane decomposition. This $\mathrm{CO}$ storage on ceria occurs through the formation of formates $\left(\mathrm{CO}+\mathrm{OH}\right.$ on reduced $\mathrm{Ce}^{3+}$ ions) as can be seen in Fig. 2c. The presence of reduced ceria is confirmed during the regeneration step: at the beginning of the pulse, $\mathrm{O}_{2}$ is firstly totally consumed before $\mathrm{CO}_{2}$ and $\mathrm{H}_{2} \mathrm{O}$ grow

Table 3

Main IR bands observed during the $\mathrm{CH}_{4}$ reaction step over A, B, C samples at $400{ }^{\circ} \mathrm{C}$

\begin{tabular}{ll}
\hline Gas phase & $3200-2800,1360-1250 \mathrm{~cm}^{-1}$ \\
Gaseous $\mathrm{CH}_{4}$ & $2390-2280 \mathrm{~cm}^{-1}$ \\
Gaseous $\mathrm{CO}_{2}$ & \\
Solid phase (Pt) & $2061 \mathrm{~cm}^{-1}(\mathrm{C})$ : gem dicarbonyl \\
Carbonyls on $\mathrm{Pt}^{\mathrm{a}}$ & $2042 \mathrm{~cm}^{-1}$ (A): linear carbonyl, \\
& $1968 \mathrm{~cm}^{-1}$ (A): bridge-bonded carbonyl \\
& $1928 \mathrm{~cm}^{-1}(\mathrm{~A}):$ multi-bonded carbonyl
\end{tabular}

Solid phase (cerium oxide for samples A and B)

Type I hydroxyl groups

Type II hydroxyl groups

Unidentate carbonate

Bidentate carbonate

Bridged carbonate

Formate

$$
\begin{aligned}
& 3720 \mathrm{~cm}^{-1}(\mathrm{~A}, \mathrm{~B}) \\
& 3640 \mathrm{~cm}^{-1}(\mathrm{~A}, \mathrm{~B}) \\
& 1066,1456 \mathrm{~cm}^{-1} \text { (A, B) } \\
& 1028,1560 \mathrm{~cm}^{-1} \text { (B) }
\end{aligned}
$$

$1015,1398 \mathrm{~cm}^{-1}$ (A)

$1378,1580 \mathrm{~cm}^{-1}(\mathrm{~A})$

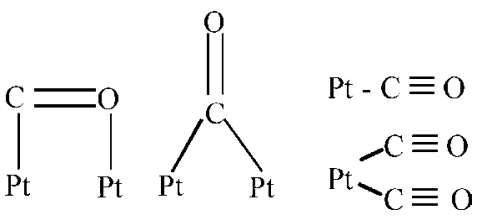<smiles>O=C(O)OC(=O)C(=O)OC(=O)O</smiles>

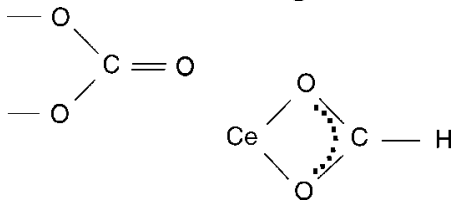

\footnotetext{
${ }^{a}$ The observation of gem dicarbonyls on $\mathrm{Pt} / \mathrm{Al}_{2} \mathrm{O}_{3}$ might come from a higher Pt dispersion, favoring the relative concentration of coordinatively unsaturated sites (CUS). Another explanation like the existence of partially oxidized Pt atoms after catalyst regeneration under oxygen (which would also lead to high frequency carbonyl bands) cannot be excluded.
} 

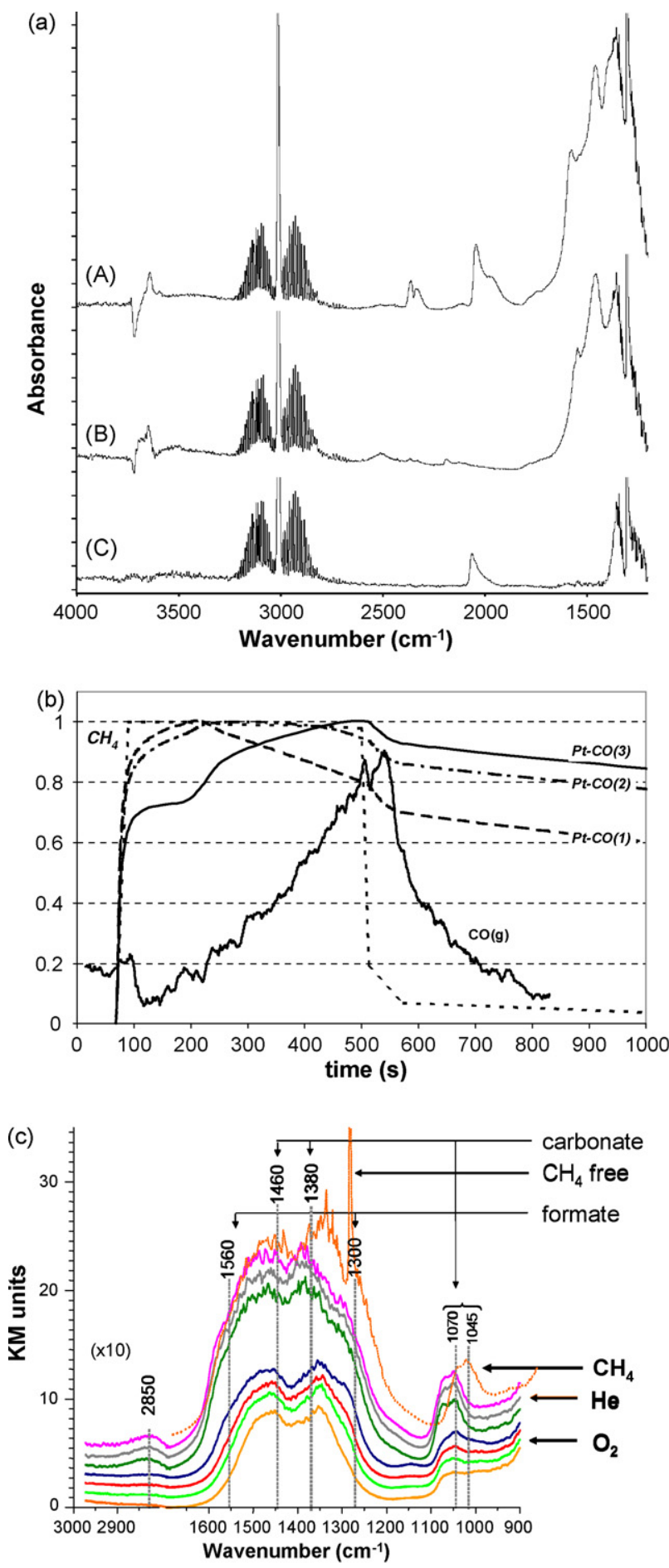

Fig. 2. DRIFT spectra at $400{ }^{\circ} \mathrm{C}$ : (a) under $\mathrm{CH}_{4}$ flow for samples A $(0.8 \% \mathrm{Pt} /$ $\left.\mathrm{CeO}_{2}\right), \mathrm{B}\left(\mathrm{CeO}_{2}\right)$ and $\mathrm{C}\left(0.5 \% \mathrm{Pt} / \mathrm{Al}_{2} \mathrm{O}_{3}\right)$, (b) changes in normalized intensity of the three main bands of carbonyl species over sample A during the $\mathrm{CH}_{4}$ pulse (Pt-CO(1): multi-bonded at ca. $1930 \mathrm{~cm}^{-1}, \mathrm{Pt}-\mathrm{CO}(2)$ : bridge-bonded at ca. $1970 \mathrm{~cm}^{-1}, \mathrm{Pt}-\mathrm{CO}(3)$ : linear at ca. $2040 \mathrm{~cm}^{-1}$ ) and (c) changes in sample A spectra (carbonate and formate wavenumbers range) during $\mathrm{CH}_{4}$ pulse, striping under $\mathrm{He}$ and regeneration under $\mathrm{O}_{2}$.

up simultaneously to a maximum after which a breakthrough of oxygen occurs. The mass balance calculations for the regeneration step show that a part of injected $\mathrm{O}_{2}$ is used to the reoxidation of the ceria $\left(\mathrm{Ce}^{3+} \rightarrow \mathrm{Ce}^{4+}\right)$.
A more quantitative approach of carbon storage can be attempted on the basis of the ceria surface potential for storing formate species. The amount of carbon stored during the methane cracking step was $138 \mu \mathrm{g} \mathrm{C} / \mathrm{g}_{\text {cat }}$ for the $0.8 \mathrm{wt} . \% \mathrm{Pt} /$ $\mathrm{CeO}_{2}$ catalyst (Table 1). OSC measurements (oxygen uptake after $\mathrm{H}_{2}$ reduction at $400{ }^{\circ} \mathrm{C}$ ) indicated that about $2870 \mu \mathrm{mol} \mathrm{O} / \mathrm{g}_{\text {cat }}$ are available during redox cycles. The commonly agreed $\mathrm{OH}$ concentration on a ceria surface can be estimated to ca. $13 \mathrm{OH} / \mathrm{nm}^{2}$ which makes a potential capacity for storing formates of $2.2 \mu \mathrm{mol} \mathrm{C} / \mathrm{m}^{2}$. For a BET surface of $130 \mathrm{~m}^{2} / \mathrm{g}_{\text {cat }}$, it makes about $286 \mu \mathrm{mol} \mathrm{C} / \mathrm{g}_{\text {cat }}$, i.e., $3432 \mu \mathrm{g} \mathrm{C} / \mathrm{g}_{\text {cat }}$. By comparing that figure to the effective storage of carbon $\left(138 \mu \mathrm{g} \mathrm{C} / \mathrm{g}_{\text {cat }}\right)$, it comes that only $4 \%$ of the capacity of carbon storage is effectively used during the cracking step (this percentage may reach $14 \%$ in the worse case after ceria severe sintering during long term runs at $600{ }^{\circ} \mathrm{C}$ ). This important statement tends to indicate that the BET surface of the ceria support is not determining for the carbon storage. Accordingly, other parameters like the diffusion rate of $\mathrm{CO}$ along the surface to reach the basic $\mathrm{OH}$ groups able to fix the carbonyl groups produced by the Pt particles should be considered. That parameter would include metal dispersion and ceria acido-basic surface properties as sensitive factors as well.

3.2.2.2. $H$ storage. $\mathrm{OH}$ groups are detected essentially in ceria containing samples (A and B). During the cracking step, two types of hydroxyl groups can be distinguished (Table 3): at high frequency (around $3720 \mathrm{~cm}^{-1}$ ) the most basic type I, which is consumed after methane admission (negative peak), while a second one at a lower frequency (around $3600 \mathrm{~cm}^{-1}$ ), type II, is accumulating. Another observation is that the IR bands of the hydroxyls are larger in the Pt containing sample A than for the Pt-free sample B. This might indicate that the Pt/ ceria interaction improves the reducibility of the support by the fast decomposition of $\mathrm{CH}_{4}, \mathrm{H}_{2}$ or $\mathrm{H}_{2} \mathrm{O}$ on $\mathrm{Pt}$ that provides reactive $\mathrm{H}$ atoms able to form $\mathrm{OH}$ groups on ceria. In the presence of $\mathrm{O}_{2}$ (regeneration step), the low frequency band at $3665 \mathrm{~cm}^{-1}$ disappears while the high frequency band at $3690 \mathrm{~cm}^{-1}$ is restored within a few seconds after exposure. This can be related to a reoxidation of the ceria surface and the generation of type I OH groups as a result of the formate oxidation/decomposition. In contrast, the more acidic type II hydroxyls are formed during the cracking step due to the reaction of hydrogen (as dihydrogen arising from methane cracking or as water arising from the initial combustion of methane) with basic ceria surface oxygen. In turn, these type II hydroxyls are decomposed during reoxidation, likely via water formation.

In order to ascertain the above mechanistic proposal, the series of IR spectra recorded after introducing methane was analyzed through the $2 \mathrm{D}$ correlation method described in Ref. [8]. The synchronous correlation analysis revealed a strong correlation between the following IR bands transients: formates, high frequency hydroxyls (linked to $\mathrm{Ce}^{3+}$ ) and carbonyls on Pt. It comes therefore that these rather basic $\mathrm{OH}$ groups are required for formate formation, in agreement with $\mathrm{Li}$ et al. [16], which supports the following reaction steps: 


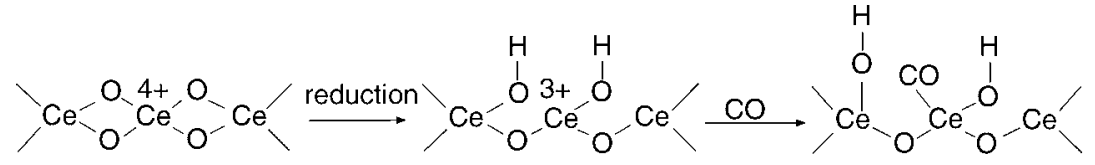<smiles>C[Ge](C)(C)O[Ge]1(O)OCO1</smiles>

where the active sites are high frequency $\mathrm{OH}$ groups linked to $\mathrm{Ce}^{3+}$ ions (or $\mathrm{Ce}^{4+}$ with oxygen vacancies), $\mathrm{CO}$ being provided as $\mathrm{Pt}$ carbonyls migrating towards the support through interfacial sites.

3.2.2.3. Role of $\mathrm{OH}$ groups for $\mathrm{C}$ storage. Among the three tested systems, only the $\mathrm{Pt} / \mathrm{CeO}_{2}$ catalyst displays both a significant $\mathrm{C}$ storage capacity and the ability to accumulate formates at the $\mathrm{CeO}_{2}$ surface. It can therefore be concluded that the formation of formates contributes directly to an efficient $\mathrm{C}$ storage, though it requires hydrogen atoms (to form the $\mathrm{OH}$ groups), provided by the $\mathrm{CH}_{4}$ decomposition, which in turn decreases the $\mathrm{H}_{2}$ yield. The other forms of carbonaceous adspecies participating to $\mathrm{C}$ storage - carbonates - are more stable therefore less adapted to fast and reversible storage. When contacted to the reducing atmosphere characteristic of the cracking step $\left(\mathrm{CH}_{4}+\mathrm{H}_{2}\right.$ mixing), the ceria surface is partially reduced by providing oxygen atoms to platinum for oxidizing the carbon atoms arising from methane cracking. In the mean time, the oxygen migration from ceria bulk to surface, necessary to maintain a fully oxidized state, is not fast enough to locally avoid $\mathrm{H}$ storage as $\mathrm{OH}$ groups arising from the reaction of hydrogen (gas phase and/or Pt-H) with surface oxygen. It can therefore be concluded that formates formation needs partially reduced ceria containing oxygen vacancies and hydroxyl groups.

\subsection{Overall scheme of the cyclic process}

From the IR study, a detailed description of the elementary steps that control the overall process is now available. The carbon issued from methane cracking is stored mainly as carbonyl, formate and carbonate species, and the hydrogen species not released in the gas phase are stored both as formate and hydroxyl groups. In analogy with proposed models for POM and WGS on similar $\mathrm{Pt} / \mathrm{CeO}_{2}$ catalysts, elementary reactions can be proposed as follows, as discussed in Ref. [4]:

$$
\begin{aligned}
& \mathrm{CH}_{4}(\mathrm{~g})+\mathrm{Pt} \leftrightarrows \mathrm{CH}_{x, \mathrm{Pt}}+(4-x) \mathrm{H}_{\mathrm{Pt}} \leftrightarrows \mathrm{C}_{\mathrm{Pt}}+4 \mathrm{H}_{\mathrm{Pt}} \\
& \mathrm{CH}_{4}(\mathrm{~g})+4 \mathrm{PtO} \rightarrow \mathrm{CO}_{2}+2 \mathrm{H}_{2} \mathrm{O}+4 \mathrm{Pt} \\
& \mathrm{C}_{\mathrm{Pt}}+\mathrm{O}_{\mathrm{Pt} / \text { supp }} \rightarrow \mathrm{CO}_{\mathrm{Pt}} \\
& \mathrm{CO}_{\mathrm{Pt}}+\mathrm{OH}_{\text {supp }} \leftrightarrows \mathrm{HCOO}_{\text {supp }} \\
& 2 \mathrm{H}_{\mathrm{Pt}} \leftrightarrows \mathrm{H}_{2}(\mathrm{~g}) \\
& \mathrm{H}_{\mathrm{Pt}}+\mathrm{O}_{\text {supp }} \leftrightarrows \mathrm{OH}_{\text {supp }}
\end{aligned}
$$

The experimental data from Fig. 1 are compared with the model curves in Fig. 3. Adequate profiles have been calculated for both methane and hydrogen curves (other products are not represented here). In particular, the long tailing of hydrogen desorption after the methane pulse is finished can be directly related to the reversibility of step (6).

These main aspects of hydrogen production under step transient conditions over the reference catalyst $\mathrm{Pt} / \mathrm{CeO}_{2}$, summarized in this first part, were used as a basis for improving the catalyst performance by changing the noble metal nature and/or concentration and by doping the ceria.

\subsection{Catalytic performances over Me/doped ceria systems}

Table 1 summarizes the performance (conversion, selectivity, hydrogen yield and carbon storage capacity) for the different Me/ doped ceria catalysts tested under cyclic conditions.

\subsubsection{Influence of temperature}

By increasing the cracking temperature from 400 to $600{ }^{\circ} \mathrm{C}$, both conversion and hydrogen selectivity, and therefore the yield, increase significantly. In turn the $\mathrm{CO}$ concentration tends also to increase, as expected from a faster oxygen release from the ceria support, able to oxidize the carbon deposits during the cracking step. Higher temperatures are also in favor of an easier desorption of $\mathrm{CO}$ adsorbed on the noble metal particles. From these statements it can be concluded that the low temperature domain is interesting for having a low $\mathrm{CO}$ concentration in the hydrogen rich effluent $(<1 \%)$ but will require methane recycling since the conversion of methane remains rather low $(\sim 22 \%)$. In turn, at $600{ }^{\circ} \mathrm{C}$, much improved hydrogen yields are obtained (up to $34 \%$ ) with the drawback of a larger CO concentration (9-10\%). This precludes any direct feeding into a state-of-the art PEMFC without downstream $\mathrm{H}_{2}$ purification, but is quite compatible for feeding a SOFC or MCFC.

\subsubsection{Influence of contact time}

By decreasing GSHV (increasing contact time) of a given system, the conversion, at $400^{\circ} \mathrm{C}$, was not proportionally

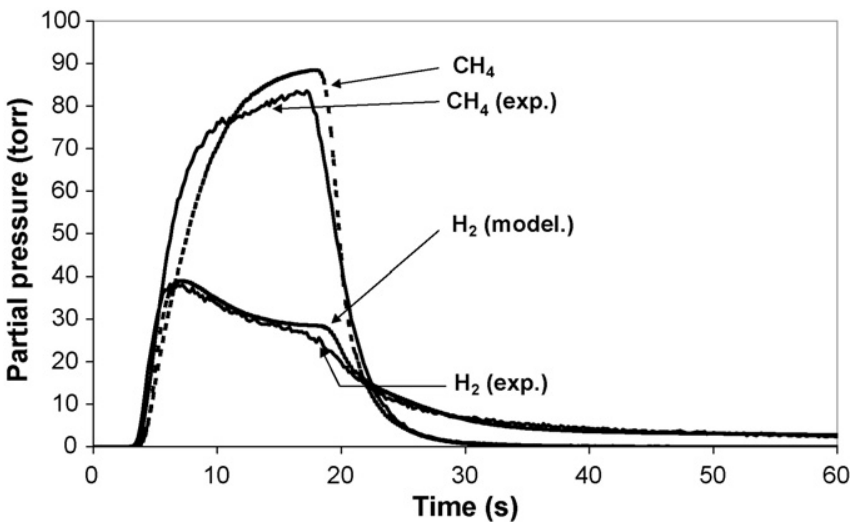

Fig. 3. Outlet gas concentrations obtained during step I over 5 wt. $\% \mathrm{Pt} / \mathrm{CeO}_{2}$ catalyst at $400{ }^{\circ} \mathrm{C}$ compared with curves calculated according to the model [10]. 
increased, as shown in Table 4 for the $0.8 \% \mathrm{Pt} / \mathrm{CeO}_{2}$ sample. This feature indicates that the cracking does not proceed under an effective catalytic regime. In turn it would be essentially controlled by the diffusion of methane cracking fragments from noble metal to support, as deduced previously from the calculation of the effective occupancy of the ceria support surface by formate adspecies (only $8 \%$ at $400{ }^{\circ} \mathrm{C}$ ).

\subsubsection{Effect of ceria doping}

Ceria-based mixed oxides $\left(\mathrm{Ce}_{x} \mathrm{M}_{1-x} \mathrm{O}_{y}\right)$ are versatile solid oxygen exchangers. At high temperatures $\left(400-800{ }^{\circ} \mathrm{C}\right)$ the redox cycle $\mathrm{Ce}^{3+} \Leftrightarrow \mathrm{Ce}^{4+}+\mathrm{e}^{-}$facilitates oxygen storage and release from the bulk fluorite lattice. This makes them ideal candidates for catalytic oxidation applications [6,7,9-12]. However, the surface redox chemistry of ceria is sensitive even at low temperatures to crystal structure defects, which can be tuned by substituting some of the Ce cations with ions of different size and/or charge [6,10,14].

By comparing the systems $\mathrm{Pt} /$ ceria and $\mathrm{Pt} /$ ceria-zirconia, detrimental effects of $\mathrm{ZrO}_{2}$ doping on hydrogen productivity were observed (worst yield at $600{ }^{\circ} \mathrm{C}$ in Table 1). Zirconia addition, known to massively improve oxygen mobility, will therefore ensure a permanent flux of oxygen towards the $\mathrm{Pt}$ surface, which will promote the oxidation of hydrogen during the methane cracking step. This flux of oxygen also explains the largest $\mathrm{CO}$ concentration observed at $600{ }^{\circ} \mathrm{C}$ for the zirconiadoped system. Therefore, in contrast with POM reaction where the zirconia doping was recognized as beneficial for the hydrogen yield $[10,14]$, the reverse effect is observed for the sequential cracking process.

At variance with zirconia, ceria doped with lanthanide oxides improved significantly the catalyst performances (best $\mathrm{H}_{2}$ yields obtained at 400 and $600{ }^{\circ} \mathrm{C}$, Table 1 ). In addition, for a given metal (e.g. Ir), ceria doped with praseodymium or lanthanum lead to an increase in $\mathrm{C}$ storage capacity and therefore a decrease in the $\mathrm{CO}_{2}$ release during the cracking step. Since this positive effect cannot be ascribed to a surface area or metal dispersion effect (both parameters did not vary in a significant way for all catalysts), it is tentatively ascribed to changes in surface properties. As a matter, higher concentration of basic $\mathrm{OH}$ groups tends to develop after lanthanide oxides doping [10,14]. This effect is likely to favor carbon trapping via carbonates and formates as shown previously by IR spectroscopy. However, the mean CO concentration was not affected by the ceria doping with lanthanides since it is essentially controlled by the enthalpy of desorption on the metal phase.

\section{Table 4}

Changes in catalytic performance with GHSV for the $0.8 \% \mathrm{Pt} / \mathrm{CeO}_{2}$ sample at $400{ }^{\circ} \mathrm{C}$

\begin{tabular}{lllll}
\hline $\begin{array}{l}\text { GHSV } \\
\left(\mathrm{h}^{-1}\right)\end{array}$ & $\begin{array}{l}\text { Conversion } \\
(\%)\end{array}$ & $\begin{array}{l}\mathrm{H}_{2} \text { selectivity } \\
(\%)\end{array}$ & $\begin{array}{l}\mathrm{H}_{2} \text { yield } \\
(\%)\end{array}$ & $\begin{array}{l}{[\mathrm{CO}] \max } \\
(\mathrm{ppm})\end{array}$ \\
\hline 1700 & 11.6 & 30.8 & 3.6 & 170 \\
3400 & 8.6 & 39.5 & 3.4 & 300 \\
8500 & 4.8 & 38.3 & 1.9 & 380 \\
\hline
\end{tabular}

\subsubsection{Effect of metal nature and dispersion}

Among the transition metals, the noble metals can be ranked according the required energy for methane dissociation, based on the theoretical calculation reported by Au et al. [17] (Fig. 4). This gives the following sequence: $\mathrm{Rh}>\mathrm{Ru}>\mathrm{Ir}>\mathrm{Pt}>\mathrm{Pd}$.

In the present study, the best catalytic results in term of hydrogen yield were obtained over Rh and Ir with or without ceria doping (Table 1) in accordance with the predicted trends. This indicates that in addition to the diffusion from metal to support, the cracking process also depends on the methane dissociation over the metallic phase. It can also be noted that the best performances of Ir and $\mathrm{Rh}$ supported catalysts were obtained with very low metal content ( $0.5 \mathrm{wt} . \%$, respectively) and the highest metal dispersion (ca. 30\%). Therefore, at this stage of the study, it can be proposed that: (i) the nature of the metal is likely to monitor the dynamics of methane dissociation and (ii) its dispersion (likely related to its content) determines the concentration of interface sites (between metal and ceria) which allow the transfer of metal carbonyls to the basic hydroxyls of the support to form formate and the reverse spillover of ceria oxygen to metal sites for oxidizing the carbon issued from methane cracking.

\subsubsection{Storage capacity}

The carbon storage capacity, calculated from the transient regeneration curves, varies from 187 to $902 \mu \mathrm{g} \mathrm{C} / \mathrm{g}_{\text {cat }}$. This indicates that a larger and larger part of the surface storage capacity (evaluated previously from the theoretical maximum concentration of surface $\mathrm{OH}$ groups) is used during the cracking step. A linear correlation is observed between the amount of converted methane and the sum of the amount of gas phase $\mathrm{CO}$ plus the amount of carbon stored on the support, thus confirming a closed carbon mass balance within the experimental error. Indeed, no straightforward relationship exists between this capacity and the hydrogen yield since the former

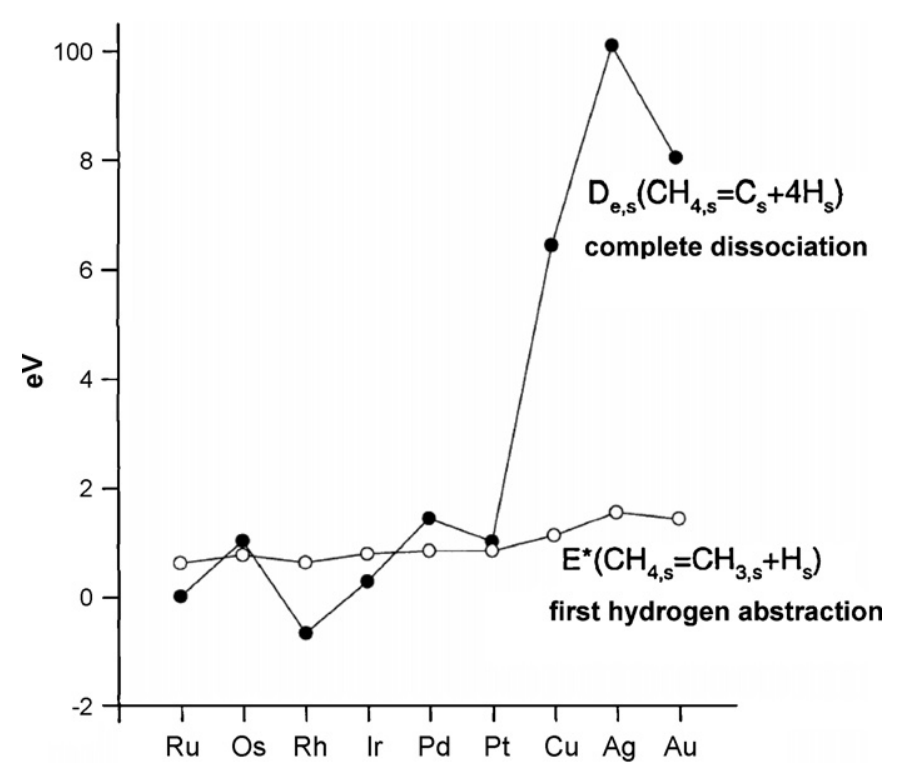

Fig. 4. Methane dissociation energy over various metals. Reproduced from Ref. [15]. 


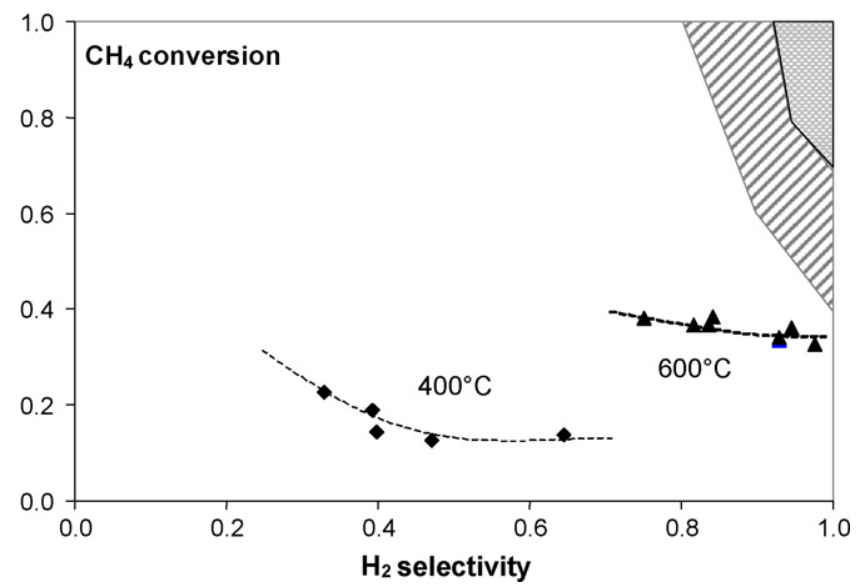

Fig. 5. Methane conversion vs. hydrogen selectivity data obtained with the sequential process at 400 and $600{ }^{\circ} \mathrm{C}$ and domains of performances for a conventional commercial POM process (dashed grey) and targeted for new process development (full grey) (unpublished data).

depends on many factors such as the basicity of the support (e.g. to accommodate carbonate species), the availability of lattice oxygen and/or defects for ensuring the formation and spillover of the various carbon-containing adspecies. In turn, the hydrogen yield is essentially controlled by the methane decomposition over the metal phase.

\subsubsection{Comparison between the best performances} achieved for the sequential and the conventional oxidative steam reforming processes

In order to assess the efficiency of this sequential process, the obtained performances in terms of conversion versus hydrogen selectivity were reported for both 400 and $600{ }^{\circ} \mathrm{C}$ on a diagram where the domains corresponding to the existing conventional POM performances and the targeted domain for the development of new processes are reported (Fig. 5).

For both temperatures, as seen above, an effective improvement of the yield is achieved by changing the process and catalysts parameters. However, it is interesting to note that all the data align along two curves essentially determined by temperature, which might indicate that improvements are still possible.

As can be seen, the best performances obtained at $600{ }^{\circ} \mathrm{C}$ compare reasonably with a commercial steady-state oxidative steam reforming process, but with the advantage of lower $\mathrm{CO}_{x}$ concentrations in the hydrogen rich feed, which might be beneficial for feeding directly a SOFC or a new generation high temperature PEMFC. In terms of hydrogen productivity, it was calculated that the sequential process could provide up to $1 \mathrm{~m}^{3} /$ $\mathrm{h} / \mathrm{kg}$ of hydrogen at $600{ }^{\circ} \mathrm{C}$, while the targeted value would be around $5 \mathrm{~m}^{3} / \mathrm{h} / \mathrm{kg}$. Thus, improvements in both the process as well as the catalyst formulations are still necessary, in order that the sequential process might be an effective alternative for transient applications in the future.

\section{Conclusion}

By investigating a sequential two-step process for producing hydrogen rich effluents from natural gas at relatively low temperature (up to $600{ }^{\circ} \mathrm{C}$ ), numerous elementary steps dealing with transfer/spillover phenomena of carbon, oxygen and hydrogen containing adspecies between the active metal and support phases were identified and quantified. In situ IR spectroscopy analysis made it possible to prove that during methane cracking over $\mathrm{Pt} / \mathrm{CeO}_{2}$ catalyst, formate species are formed via the direct reaction of $\mathrm{CO}$ carbonyls with basic $\mathrm{OH}$ groups of ceria surface vibrating at $3720 \mathrm{~cm}^{-1}$. The reactivity of the latter, associated with a high rate of surface diffusion, originates the catalyst capacity for storing carbon quantitatively and reversibly. Significant improvements of this storage capacity and therefore of the hydrogen productivity were achieved both by changing the metal phase to $\mathrm{Ir}$ and $\mathrm{Rh}$ as predicted from theory and by doping the ceria support by basic lanthanide oxides to increase the concentration of these reactive $\mathrm{OH}$ groups.

By comparing the best performances obtained with the sequential process and with a conventional oxidative steam reforming processes it was concluded that the sequential process might be an alternative for transient applications in the future.

\section{Acknowledgements}

Air Liquide is fully acknowledged for partial support of that work and providing reference data for the commercial POM process. Rhodia is acknowledged for kindly providing the undoped and doped ceria samples.

\section{References}

[1] Z. Li, N. Cai, J. Yang, Ind. Eng. Chem. Res. 45 (2006) 8788.

[2] T. Zhang, M.D. Amiridis, Appl. Catal. A 167 (1998) 161.

[3] T.V. Choudary, D.W. Goodman, Catal. Lett. 59 (1999) 93.

[4] E. Odier, Y. Schuurman, H. Zanthoff, C. Millet, C. Mirodatos, Stud. Surf. Sci. Catal. 133 (2001) 327.

[5] S.D. Park, J.M. Vohs, R.J. Gorte, Nature 404 (2000) 265.

[6] G. Rothenberg, E.A. de Graaf, A. Bliek, Angew. Chem. Int. Ed. 42 (2003) 3066.

[7] D. Tibiletti, E.A.B. de Graaf, G. Rothenberg, D. Farrusseng, C. Mirodatos, J. Catal. 225 (2004) 489

[8] E. Odier, Y. Schuurman, K. Barral, C. Mirodatos, Stud. Surf. Sci. Catal. 147 (2004) 79.

[9] V. Perrichon, L. Reteilleau, P. Bazin, M. Daturi, J.C. Lavalley, Appl. Catal. A 260 (2004) 1.

[10] T.G. Kuznetsova, V.A. Sadykov, E.M. Moroz, S.N. Trukhan, E.A. Paukshtis, V.N. Kolomiichuk, E.B. Burgina, V.I. Zaikovskii, M.A. Fedotov, V.V. Lunin, E. Kemnitz, Stud. Surf. Sci. Catal. 143 (2002) 659.

[11] S. Bernal, J.J. Calvino, M.A. Cauqui, J.M. Gatica, J.A. Pérez Omil, J.M. Pintado, Catal. Today 50 (1999) 175.

[12] C. Li, Y. Sakata, K. Domen, K. Maruya, T. Onishi, J. Chem. Soc. Faraday Trans. 85 (1989), 929 and 1451.

[13] C. Bozo, N. Guilhaume, E. Garbowski, M. Primet, Catal. Today 59 (2000) 33.

[14] V.A. Sadykov, T.G. Kuznetsova, Yu.V. Frolova-Borchert, G.M. Alikina, A.I. Lukashevich, V.A. Rogov, V.S. Muzykantov, L.G. Pinaeva, E.M. Sadovskaya, Yu.A. Ivanova, E.A. Paukshtis, N.V. Mezentseva, L.Ch. Batuev, V.N. Parmon, S. Neophytides, E. Kemnitz, K. Scheurell, C. Mirodatos, A.C. van Veen, Catal. Today 117 (2006) 475.

[15] T. Jin, T. Okuhara, G.J. Mains, J.M. White, J. Phys. Chem. 91 (1987) 3310.

[16] C. Li, Y. Sakata, T. Arai, K. Domen, K. Maruya, T. Onishi, J. Chem. Soc. Faraday Trans. 85 (1) (1989) 1451.

[17] C.T. Au, C.F. Ng, M.S. Liao, J. Catal. 185 (1999) 12. 